Sarita Soraia de Alcântara Laudares ${ }^{1+}$, Luís Antônio Coimbra Borges', Patrícia Andressa de Ávila', Athila Leandro de Oliveira², Kmila Gomes da Silva', Dagmar Cristina de Alcântara Laudares ${ }^{3}$

\title{
AGROFORESTRY AS A SUSTAINABLE ALTERNATIVE FOR ENVIRONMENTAL REGULARIZATION OF RURAL CONSOLIDATED OCCUPATIONS
}

Keywords:

Brazilian Forest Code

Small farmer

Agroforest

Histórico:

Recebido 03/10/2016

Aceito $31 / 03 / 2017$

Palavras chave:

Código Florestal

Pequeno produtor rural Agrofloresta

+Correspondência: saritalaudares@gmail.com

$\mathrm{DOI}$
ABSTRACT: The great expectation about the New Forest Code consisted in reducing the hermeneutics distortions and increasing legal certainty for farmers. However, the new legislation raised more uncertainties and discussions, mainly because it consolidates the anthropic use and allows of low-impact activities in areas that should, by law, be kept untouched. This study aimed to survey and to describe the legislation related to protected areas on the rural area (APP and RL), to analyze the consolidated forms of use, occupation and low impact activities that can be developed in these areas, and to propose sustainable technical alternatives for interventions in the areas already consolidated and their recovery. The text is based on literature and documents, elaborated on the survey and study of legal aspects about protected areas in rural properties of Brazil and the main low-impact farming techniques, highlighting the agroforestry systems as an alternative of consolidated occupations in environmental protection areas. The text provides in an organized way the main aspects of the legislation on such areas and describes the sustainable activities allowed in APP and RL according to the flexibility of the new Forest Code.

\section{SISTEMAS AGROFLORESTAIS COMO ALTERNATIVA SUSTENTÁVEL PARA REGULARIZAÇÃO AMBIENTAL DE OCUPAÇÕES RURAIS CONSOLIDADAS}

RESUMO: A grande expectativa acerca do Novo Código Florestal consistiu-se em reduzir as distorções da hermenêutica e aumentar a segurança jurídica dos produtores rurais. Contudo, a nova legislação suscitou mais incertezas e discussões, principalmente, ao consolidar o uso antrópico e a permissão de atividades de baixo impacto ambiental em áreas que deveriam, por lei, ser mantidas intocadas. Este trabalho teve como objetivo levantar e descrever a legislação relacionada às áreas de proteção na propriedade rural (APP e RL), analisar as formas de uso-ocupação consolidados e de baixo impacto que podem ser desenvolvidos nestas áreas, bem como, propor soluções técnicas sustentáveis para intervenções nas áreas já consolidadas e recuperação das mesmas. O Sistema Agroflorestal constitui uma alternativa estratégica de intervenção e recuperação das APPs e RLs àqueles pequenos produtores que ainda não estão em conformidade com a Lei. As propriedades rurais devem sempre procurar inovar, diminuindo custos de produção e aumentando a lucratividade com responsabilidade ambiental e o sistema agroflorestal tem-se mostrado uma alternativa que congrega produção com proteção ambiental.

'Federal University of Lavras - Lavras, Minas Gerais, Brazil

${ }^{2}$ Federal Rural University of Rio de Janeiro - Seropédica, Rio de Janeiro, Brazil

${ }^{3}$ President Antônio Carlos Foundation - Bom Despacho, Minas Gerais, Brazil 


\section{INTRODUCTION}

Nowadays, the environmental sustainability has been projected as a high relevance subject. Around the world, it has been very discussed the predatory relationship that characterizes the modern ways of production and the necessity of changes in the treatment of natural resources.

Sustainable development, or sustainability, is a broad concept that has been constantly updated, and sometimes, is discredited by scientists. However, sustainable development is very important to stop the economic development at any cost, which Braga et al. (2004) reports as a symbolic battlefield and a powerful tool of marketing consolidated of relationship patterns between environmental conservation and economic growth.

The conception of sustainability here adopted is a precursor from other concepts, which was elaborated by World Commission on Environment and Development. In its final document, known as Brundtland Report, it was understood the definition: "is development that meets the needs of the present without compromising the ability of future generations to meet their own needs".

On the need to ensure the sustainability to the environment, the public power defined in all the units of the Federation, distinct and complementary territorial spaces and their components that should be protected. As a result, limitations were enforced by the forest law about the use of rural properties that should be considered as Areas of Permanent Preservation (APPs) and Legal Reserve (RLs).

The APPs are protected areas, covered or not by native vegetation, with the ecological function of preserving hydrological resources, landscape, geological stability, biodiversity, fauna and flora, to protect soil and ensure the wellbeing of the human populations. In addition, the RL corresponds to the localized area within a rural property or possession with the function of preserving the sustainable socioeconomic use of the natural resources, to the conservation and rehabilitation of the ecological processes and the conservation of biodiversity (BRASIL, 20I2).

As can be seen in the APPs and RLs definitions, these areas are very favorable to the farmers because of the several environmental services provided by them, such as refuge for migratory species that could be used in the biological control of pests, seed banks of primary vegetation, prevention of soil erosion and also provide continuity and production of the natural resources. However, even with all the benefits supplied to the farmers, APP and RL have been considerably degraded by agricultural practice.
Historically, since the Brazilian colonization, agriculture has been one of the economic bases of the country. In addition to meeting the demand by agricultural and food products, it has an important role in the sequestration of carbon, preservation of biodiversity and management of watersheds. However, the lands destined to agriculture make use of natural resources, which if badly managed can contribute to the exhaustion of soil, pollution by agrochemicals and climate changes in the world. Other important factor of environmental degradation caused by agricultural practices is the competition in the agricultural sector. Aiming increasing productivity, the agricultural expansion and, consequently, the removal of vegetation, may result in mistakes and excesses in the management of crops, causing irreversible impacts.

The natural resources degradation suppresses the base to future agricultural production and increases vulnerability to risks, resulting in significant economic losses. Sometimes, these costs can be minimized by combination of technological innovations, institutional innovation and policy reforms.

It is in this context that forestry system is inserted as a sustainable alternative of activity in the Areas of Permanent Preservation and Legal Reserve of small farms. In these protected areas, the Brazilian legislation established by Forest Code, the Law $n^{\circ} 12.65$ I, which was approved in late of 2012 , allows the continuation of consolidated activities before July $28^{\text {th }}$ of 2008 , in addition to activities defined as low-impact activity.

This work aimed to review and describe the main related aspects about the areas of protection in rural properties (APP and RL), to analyses forms of use and consolidated occupation and low impact that could be develop in these areas. The paper is based on bibliographical and documentary research, elaborated from survey and studies of legal aspects about protected areas in rural farms in Brazil and the main techniques of low-impact farming, highlighting the agroforestry systems as an alternative of consolidated occupations in the protection areas. As a result, this document gathers the main aspects of legislations about these areas and describes the sustainable activities allowed according to the flexibility of the new Forest Code.

\section{LEGAL ASPECTS AND IMPORTANCE OF APP AND RL}

\section{Areas of Permanent Preservation (APP) in the countryside}

The conservation of forests and other kinds of native vegetation is fundamental to protect the original 
fauna and flora of each region. The Brazilian legislation has among its instruments, the Area of Permanent Preservation (APP) and Legal Reserve (RL), ensuring the environmental conservation. As described in the Art. 4 of the Law $n^{\circ} 12.65 \mathrm{I}$ of 2012 , it is considered APP, in rural or urban areas:

a. The marginal strips of any natural watercourse, from the edge of the regular stream channel, with minimum width of (Table I).

TABLE I APP width in relation to watercourse.

\begin{tabular}{cc}
\hline Watercourse width $(\mathrm{m})$ & APP width $(\mathrm{m})$ \\
\hline$\leq 10$ & 30 \\
$10-50$ & 50 \\
$50-200$ & 100 \\
$200-600$ & 200 \\
$>600$ & 500 \\
\hline
\end{tabular}

b. Areas surrounding natural lakes and ponds.

In rural areas, 100 (one hundred) meters, except for water bodies with surface areas of up to 20 (twenty) hectares, whose buffer width shall be 50 (fifty) meters;

\section{c. Areas surrounding artificial reservoirs.}

Resulting of damming of natural watercourses, in area defined in environmental license of enterprise. According to Art. 5, in artificial reservoirs destined to produce energy in rural area, the minimum area surrounding of preservation shall be 30 (thirty) meters and maximum area shall be 100 (one hundred) meters;

d. Areas surrounding the water source and perennial water eye, whatever the topography in a minimum radius of 50 (fifty) meters;

e. All areas with slope higher or equal to 45 degrees, equivalent to $100 \%$ (one hundred percent) in the line of maximum gradient;

f. Areas of restinga vegetation, resulting in fixing of dunes or stabilization of mangroves;

g. The mangroves in all their extension;

h. The edge of coastal plains (in Portuguese Tabuleiros) or tablelands (in Portuguese Chapadas), up to the break line of the relief with the strip never lower than 100 (one hundred) meters in horizontal projections; i. Hilltops and ridges with minimum height of 100 meters and mean slope $\geq 25 \%$, not specifying maximum height. Hilltops defined as areas situated above two-thirds of the total height, where the baseline is defined as horizontal surface of the adjacent plain or water surface, or on the nearest saddle point in undulated terrain;

j. Elevation higher than 1.800 (one thousand and eight hundred) meters, whatever the present vegetation;

k. In vereda areas, the marginal range, in horizontal projection, with a minimum width of 50 (fifty) meters from the boundary of drenched space.

When declared by act of the chief of Executive Power, it is considered APP (Art. 6) the areas covered with forest or other vegetation destined to one or more of the following aims: prevent soil erosion and mitigate risks of floods and land and rock sliding; protect thes restinga vegetation or vereda areas; protect floodplains (in Portuguese Varzea); sheltering specimens of fauna and flora that are endangered; protect sites with exceptional beauty with scientific, cultural or historical value; assist the defense of national territory, at military authorities discretion; and among others.

\section{Importance of Area of Permanent Preservation (APP)}

The importance of APPs can be represented in two aspects: as physical components of agroecosystem and the second, in relation to ecological services provided by the existing flora, including all the associations with the biotic and abiotic components of agroecosystem (BORGES et al., 201 I, SILVA et al., 201 I, SKORUPA, 2003 and TUNDISI and TUNDISI, 20I0).

Skorupa (2003) still discusses some ecological importance such as: I) generation of sites to natural enemies of pests to feeding and breeding; II) providing shelter and food (pollen and nectar) for insect pollinators of crops; III) refuge and food for terrestrial and aquatic fauna; IV) genic flow corridors to the elements of flora and fauna by the possible interconnection of adjacent APP or areas of Legal Reserve; V) detoxification of toxic substances from agricultural activities by bodies of meso and micro fauna associated with plant roots; $\mathrm{VI}$ ) recycling of nutrients, and VII) carbon fixation. These facts reinforce the need to prohibit or restrict the exploration in some areas essential to the maintenance of biodiversity. 
As these physical and ecological functions are complementary not enough to establish a minimum amount of vegetation, it is necessary to have adequate vegetation cover in each position of the relief so that all environmental functions are properly provided (TAMBOSI et al., 2015).

\section{Limitations of use, intervention and forms of regularization of Area of Permanent Preservation (APP)}

The Forest Code and the CONAMA resolution $n^{\circ} 369$ of 2006, say that the protection of APPs is very strict, affirming that these areas should be kept untouched. The intervention or suppression of native vegetation is allowed only in case of public utility, social interest or low-impact activities. In the case of protective native vegetation of water source, dunes and restinga vegetation, the removal of protective native vegetation is even more restrictive and is authorized only in case of public utility.

The Law $n^{\circ} 12.651$ of 2012 does not define the low-impact activities, public utility and social interest. However, these terms are characterized in its Art. 4:

\section{Public utility}

a. The national security activities and health protection;

b. Infrastructure works destined to concessions and to public transport services, road system, including that necessary to urban land use approved by the municipalities, sanitation, waste management, energy, telecommunications, broadcasting, facilities required to carry out state, national or international sports competitions, as well as mining, except in the last case, the extraction of sand, clay and gravel;

c. Activities and civil defense works;

d. Activities that provide improvements in the protection of environmental functions referred in section II of this article, showing the improvement of the functions of the Permanent Preservation Areas;

e. Other similar activities characterized and motivated by own administrative procedure, when there is no technical and locational alternative to the proposed development, defined by act of the Chief of Federal Executive.

\section{Social interest}

a. Essential activities to protect the integrity of native vegetation, such as prevention, combat and control the fire, erosion control, eradication of invasive and protection plantations with native species;

b. Sustainable agroforestry exploration practiced in small or rural family property, or by traditional people and communities, since their activities do not mischaracterize the present vegetation and not damage the environmental function of the area;

c. The implementation of public infrastructure destined to sports, leisure and educational and cultural activities outdoor in consolidated urban and rural areas, defined the conditions established in this law;

d. Regulation of land use of human settlements occupied predominantly by low-income population in consolidated urban areas, considering the conditions established in Law I I.977 of July $7^{\text {th }}$ of 2009 ;

e. Implementation of facilities necessary for collecting and carrying water and treated effluent to projects whose water resources are integral and essential parts of activity;

f. Research activities and extraction of sand, clay and gravel, granted by the competent authority;

g. Other similar activities properly characterized and motivated by an administrative procedure, when there is no technical and locational alternative to the proposed activity, defined by act of the Chief of Federal Executive.

The CONAMA resolution $n^{\circ} 425$ of 2010 , defines exceptional cases of social interest where the competent environmental agency can regularize the intervention or removal of vegetation on consolidated APP until July $24^{\text {th }}$ of 2006:

I. Maintenance of the traditional extensive grazing in areas with vegetation of high fields, since this activity does not promote additional suppression of the native vegetation or the introduction of exotic plant species;

II. The maintenance of crops with perennial woody or fruit species, which are not allowed to seasonal shallow cuts, since the management practices used to ensure the environmental function of the area in all its extension, including the elevations with slope 
greater than 45 degrees and hill top;

III. The activities of sustainable agroforestry management, since they do not mischaracterize the cover vegetation and do not damage the environmental function of the area; and

IV. Seasonal activities of the ebb agriculture, traditionally practiced by family farmers, specifically for growing temporary crops of short cycle, in the strip of land that is exposed at low tide period of rivers or lakes, since not involving removal and conversion of areas with native vegetation, in the use of agrochemicals and cultural practices that affect water quality.

Searching for organizing the understanding about these occupations, the Forest Code of 2012 recognized the importance of defining these activities, as following:

\section{Activities of low environmental impact}

a. Opening of small roads of internal access and their bridges, when they are necessary for crossing a stream, accessing of people and animals to obtain water or withdrawal of products derived from sustainable agroforestry activities;

b. Implementation of facilities necessary for collecting and carrying water and treated effluent, since proved the granting of right to use the water, when appropriate;

c. Implantation of trails for the development of ecotourism;

d. Building of launching pad for boat and small harbor;

e. Construction of housing for family farmers, remnants of Quilombo communities and other extractive and traditional populations in rural areas where the water supplied by resident efforts;

$f$. Construction and maintenance of fences in the property;

g. Scientific research on environmental resources, respecting other requirements of current legislation;

h. Harvesting of non-timber products for subsistence and seedling production, such as seeds, nuts and fruits, respecting the specific legislation of accessing to genetic resources;

i. Plantation of fruit native species, seeds, nuts and other vegetable products, since these activities do not involve removal of current vegetation, and also do not damage the environmental function of area;

j. Agro-forestry exploration and sustainable forest management, community and family, including the extraction of non-timber forest products, considering that they do not ischaracterize the current native vegetation or harm the environmental function of area;

k. Other actions or similar activities, recognized as eventual or low environmental impact in the act of the National Environmental Council CONAMA or the State Environmental Councils.

Finally, with the edition of the Law $n^{\circ} 12.65$ I of 2012, there was an attempt to regularize activities in APPs when they were considered low-impact activities, which facilitated further to the small rural property.

The removal of vegetation from Area of Permanent Preservation depends on approving of environmental agencies, and it will be allowed in the boundaries predicted in the Forest Code, which does not dispense mitigating and compensating actions. Consequently, when the APP vegetation is removed with authorization, the land owner or occupant in title is required to execute the restoration of this vegetation.

In addition to the above activities allowed, the Forest Code authorizes the continuation of agroforestry activities, ecotourism and rural tourism in rural areas consolidated until July $22^{\text {th }}$ of 2008 , even in the APPs located in properties that share a border with protected areas, considering the existence of a prepared and approved Management Plan in accordance with guidelines issued by the organ of SISNAMA.

It will be observed in activities some technical criteria for soil and water conservation, being prohibited the conversion of new areas for alternative use. Furthermore, these properties will be required to restore the Area of Permanent Preservation in accordance with the size of the property and, in some cases, also in accordance with the width of the stream, as shown in Table 2.

Considering rural properties that have consolidated area in APP, the recovery of their marginal strips since the edge of the regular stream channel is mandatory, independently of stream's width. For regularization of areas on the stream's banks is necessary to understand the concept of fiscal modules (MFs).

Fiscal module is a unit of measure, which considers for its calculation: the predominant type of farm in the municipality; the proceeds from the predominant exploitation; and other current holdings, even if they are not predominant, but they are significant if considered income or used area; apart from the concept of family property. The modules range 5-I 10 hectares, according to the municipality. 
TABLE 2 Minimum recomposition APP according to the size of the rural property tax in modules.

\begin{tabular}{|c|c|c|c|c|}
\hline $\begin{array}{c}\text { Area of rural } \\
\text { property } \\
\text { (fiscal module) }\end{array}$ & $\begin{array}{c}\text { Marginal } \\
\text { strip } \\
(\mathrm{m})\end{array}$ & $\begin{array}{c}\text { Area } \\
\text { surrounding } \\
\text { water sources } \\
(\mathrm{m})\end{array}$ & $\begin{array}{c}\text { Area } \\
\text { surrounding } \\
\text { natural lakes } \\
\text { and ponds } \\
\text { (m) } \\
\end{array}$ & $\begin{array}{c}\text { Area } \\
\text { surrounding } \\
\text { veredas areas } \\
(\mathrm{m})\end{array}$ \\
\hline$\leq 1$ & 5 & 15 & 5 & 30 \\
\hline$>1$ a 2 & 8 & 15 & 8 & 30 \\
\hline$>2$ & 15 & 15 & 15 & 30 \\
\hline$>2 \mathrm{a} 4$ & 15 & 15 & 15 & 30 \\
\hline$\leq 4$ & 15 & 15 & 15 & 30 \\
\hline$>4$ a 10 & * & 15 & 30 & 50 \\
\hline$>4$ & * & 15 & 30 & 50 \\
\hline
\end{tabular}

* According to the environmental recovery plan, considering a minimum of $20 \mathrm{~m}$ and a maximum of 100 meters.

This unit of measurement was used as a parameter to classify the size of the farms: small (up to 4 MFs), medium (4-I5 MFs), large (greater than I5 MFs). This way, the strip that should be regularized will have a variable width according to the number of the MFs of the rural property. Minimum of 5 meters for areas with up to I MF, 8 meters for areas larger than I MF up to 2 MFs, and 15 meters for areas larger than 2 up to 4 MFs. Considering properties that have areas larger than $4 \mathrm{MFs}$, the extension will be estimated according to the environmental recovery plan, observed the minimum of twenty meters and maximum of one hundred meters.

In the case of consolidated rural areas surrounding water source and perennial water eye, it is mandatory the area recovery in a minimum radius of fifteen meters.

Considering rural properties that surrounding lakes and natural ponds, the recovery of minimum strip is five meters for properties with up to one fiscal module, eight meters for properties with area larger than one fiscal module up to two modules, fifty meters for properties with area larger than two modules up to four fiscal modules, and thirty meters to properties with area larger than four fiscal modules.

Finally, the Forest Code of 2012 states the obligation of recovering veredas in consolidated areas. The recovery should be in marginal strips in horizontal projection, delimited from the soggy area with minimum width of thirty meters for properties with an area up to four fiscal modules and fifty meters for properties with an area higher than four fiscal modules.

Looking for assisting owners and possessors of rural properties that, in July $22^{\text {th }}$ of 2008 , had up to four fiscal modules and developed agroforestry activities in the consolidated areas in APP, is guaranteed that the recovery requirement, added all APPs of the property do not exceed ten percent of the total of property's area with up to two fiscal modules and twenty percent for areas between two and four fiscal modules.

The recovery can be made: I) alone or jointly; II) by conducting the natural regeneration of native species, III) planting of native species; IV) planting native species conjugate with the conduction of the natural regeneration of native species; and V) by planting woody species, perennial or long cycle, in which case is allowed the planting of native and exotic plants for small properties or rural family property (BRASIL, 20I2).

It is also authorized by Law $n^{\circ} 12.65 \mathrm{I} / \mathrm{I} 2$, the maintenance of forest activities, cultivation of woody species, perennial or long cycle and the physical infrastructure associated with the development of agroforestry activities in consolidated areas in slopes, edges of coastal plains or tablelands, hilltop, mountain, and altitudes higher than one thousand and eight hundred meters. It is important to observe that these activities are conditioned to the adoption of soil and water conservationist practices indicated by the technical and rural assistance agencies.

\section{Legal Reserve}

Legal Reserve $(R L)$ is the delineated area inside a rural property or possession with function to ensure the sustainable economic use of natural resources of rural property, to assist in conservation and rehabilitation of ecological processes, and promote biodiversity conservation, as well as to shelter and to protection and wildlife and native flora (BRASIL, 20I2).

The $R L$ area varies from region to region, according to Brazilian Forest Code. In the Art. I 2 of Brazilian Forest Code is defined that all rural property should keep area with native vegetation as $\mathrm{RL}$, considering the minimum percentage in relation to property area: $80 \%$ of $\mathrm{RL}$ in property situated in Amazon; $35 \%$ of $\mathrm{RL}$ in property situated in cerrado: $20 \%$ of $\mathrm{RL}$ in property situated in savannas. The percentage of $R L$ in property located in area of forests, cerrado or savannas, will be defined considering separately the rates above, and $20 \%$ of the property area located in other regions of the country.

According to Forest Code, Art. 14, are indicated some studies and criteria to the location of Legal Reserve area, which should be taken into consideration in the moment of its implementation, resulting in further protection and maintenance of environmental balance on the property: I) the watershed plan; II) the EcologicalEconomic Zoning (EEZ) because it is related to land use 
capacity, and the Executive Branch may reduce the $\mathrm{RL}$ up to $50 \%$ of the property, aiming to recovery the Legal Amazon, or widen to $50 \%$ the $\mathrm{RL}$ in any other region of Brazil; III) the formation of ecological corridors with another Legal Reserve, with APP, with Conservation Unit or other legally protected area; IV) the areas of greatest importance to biodiversity conservation; and V) the areas of greatest environmental fragility.

Every rural property should have your RL, obeying the law requirements in the region where it is located, and then it will be approved by the competent organ through registration record in the Rural Environmental Registry (Portuguese acronym, CAR). In case of rural property fractionation, in any title, including settlements for Agrarian Reform Program, will be considered the property of the area before the fractionation.

\section{Importance of Legal Reserve}

The Legal Reserve also has its importance for conservation of natural resources because it works as reservoir of biodiversity, as a refuge for migratory species, is the primary vegetation seed banks and mitigates erosion, winds, excessive temperature and exposure of soil to sun. The Legal Reserve enables the formation of ecological corridors, conservation of endemic species, in-situ conservation of genetic diversity. Moreover, it is a sustainable source of logs, wood, fruits, medicinal plants, sale of carbon credits, and make possible to get incentives by the government, such as "Green Grant". In addition of its importance, it was necessary to define limitations of the use for RL, searching for perpetuating of natural resources for future generations.

\section{Limitations of use, intervention and forms of regularization of Legal Reserve}

The $\mathrm{RL}$ protection regime is not inexorable. The owner of the land, possessor or occupant for any reason of the legal reserve, must preserve it with native vegetation and not suppress it. However, it has been accepted the economic exploitation if a sustainable management is applied. This way, it is forbidden: I) clearcutting where the harvesting of all trees of a part of forest population, leaving the land temporarily free of vegetation and in a difficult regeneration state.; II) the use of pesticides that can promote the same results of clearcutting and; III) the land alternative use, which replaces the native vegetation and succeeding formations by other ground covers, such as agricultural activities, mining, settlements and other forms of human occupation (BRASIL, 20I2).

It is worth mentioning the concept of small property or rural family possession. By law, the term is defined as the property exploited by personal work of family farmer and rural family entrepreneur, including the settlements and land reform projects, and that meets the legal requirements: not have, to any title, area larger than four fiscal modules; predominantly use manpower of his own family in the economic activities of the establishment or enterprise; have minimum percentage of family income arising from economic activities of their establishment or enterprise, as defined by the Executive Power; and manage the establishment or enterprise with his family.

The sustainable management of RLs vegetation of rural small property or rural family possession with commercial purposes depends on simplified authorization of the competent agency and must submit at least the following information: owner or rural possession data, data of rural property or possession and sketch of the property area indicating the area that will be applied selective management, estimating the volume of forest products and by-products that will be obtained with the selective management, indication of their destination and planned implementation schedule.

On the other hand, the sustainable management of RLs forest vegetation used in the property consumption itself will adopt selective exploitation practices, which not depends on competent bodies authorization, and should only be previously declared to the environmental agency the reason of exploitation and the exploited volume, being limited the annual operating in two cubic meters per hectare of wood, and it should not be largest than fifteen percent of the RLs biomass and not exceed fifteen cubic meters of wood for domestic energy use and for rural property or possession in one year (BRASIL, 20I2) .

The exceptions to RL suppression are the sporadic activities or low-impact environmental activities, as long as they are authorized by the competent environmental agency. The person who does not comply with Law $n^{\circ} 12.651$ of 2012 by omitting contrary actions to it, even if there is no regularization, may be punished civil, administrative and criminally by the Environmental Crimes Law (Law n9.605 of 1998), having to pay with repair of the environmental damage. The Art. I5 of the Forest Code also facilitates the regularization for those who not have the least of native vegetation remnant required by the law to fulfill with $\mathrm{RL}$ because it allows the accumulation of APP in the percentage calculation of $R L$, if they follow some conditions, such as: the benefit provided in the article does not involve conversion of new areas for alternative land use; the area to be accumulated must be kept or in recovery process; and 
the owner or possessor of the area must be included in Rural Environmental Registry System (Portuguese acronym, SICAR). Currently, the code provides this inclusion when the sum of APP with RL exceeds $80 \%$ of the property in the Legal Amazon. If in addition to APP and RL computation, the owner does not have the area of native vegetation in $\mathrm{RL}$ defined for each Brazilian region, it is possible to choose the following alternatives alone or together:

I) RL recovery of property: by the intercalated plantation of exotic and native species, maximum of fifty percent of the area that needs to be recovered in agroforestry system combined with native species. The restoration must meet the established criteria by the competent body and be completed within 20 (twenty) years, covering at least $\mathrm{I} / \mathrm{I} 0$ (one tenth) of the total area required for its completion every 2 years.

II) Permission of natural regeneration of vegetation in the area of Legal Reserve, which must be authorized by the competent state environmental agency when their viability is proven by a technical report, and it is able to require area isolation too.

III) Registration of another equivalent area and surplus to RL in a property of same owned or acquired property of other part with established native vegetation, which must be in regeneration or restoration, when located in the same biome. The areas that will be used for compensation should be equivalent in size to the $\mathrm{RL}$ area to be compensated, be located in the same biome of $\mathrm{RL}$, be outside of the state, and be located in areas identified as priorities by the Union or by the states.

According to Law $n^{\circ} 12.651$ of 2012 , the rural properties with up to four fiscal modules that held until July $22^{\text {th }}$ of $2008 \mathrm{RL}$ area in extension lower than that established by this law, may constitute the RL with the existing native vegetation in this date, being prohibited new conversions to alternative land use. That is, if a property has less than four fiscal modules - which can have until four hundred hectares in some regions of Brazil - not even have $1 \%$ of native vegetation to form the Legal Reserve, it may be excused from fulfill such obligation.

\section{FLEXIBILITY OF ENVIRONMENTAL LAW AND WHY TO IMPLEMENT AGROFORESTRY SYSTEMS}

In summary, the Law $n^{\circ} 12.651$ of 2012 has several flexibilities that minimize the environmental protection, mainly for those who used Area of Permanent Preservation and Legal Reserve, such as: I) the approval of the continuity of agroforestry activities, ecotourism and rural tourism in rural areas consolidated until July $22^{\text {th }}, 2008$; II) amnesties through regularization program to be created by the government to these areas; III) lack of low-impact activities conceptualization as well as your permission in APP. Nevertheless, it reduces the protection of areas to be permanently preserved as strips along watercourses (measured from the edge of the regular bed rather than the edge of the largest seasonal one) and regions of hills (only be considered APPs of hilltops with minimum height of 100 meters and higher average slope $25^{\circ}$, instead of the minimum height of 50 meters and an average slope higher than $17^{\circ}$ as was in the older code).

In relation to consolidated use, both the minimum metreages to be recovered in "wet APPs" (along rivers, lakes or reservoirs, natural or artificial, springs and veredas) and the permission of the activities continuity in "APPs in hilltops" (tops, slopes and edges of trays or plateaus), through sustainable management, and also the release of the recomposition of the RL by small farmers, minimize the protection and compromise the environmental function of these areas. The parts to be recomposed become too small to fulfill its function and expression of sustainable management, being very wide, open gaps for carrying out unsustainable activities. According to Soares-Filho (20l4), these legislative changes that reduce the need to restore native vegetation, decreases by $58 \%$ the potential area to be recovered under the previous legislation.

Brancalion et al. (2016) reported that the main throwback arising from the new legislation were based on the granting of amnesty fines imposed for violations of existing law, permission of the maintenance of agricultural and infrastructure activities in protected areas without the need for total native vegetation recovery and removal of environmentally sensitive areas of protection. These author also highlight that it is necessary to establish stimulus mechanisms to develop the business chain of recovery of native vegetation.

The use of techniques to minimize anticonservation effects found in law gaps becomes essential to keep the environment itself. The agroforestry systems (Portuguese acronym, SAF) emerge as alternative prototypes to be implemented in APPs and consolidated reserves since, compared to monocultures, provides greater diversity to the environment, raising the gene flow and ecological interactions in these locations. SAFs is advantageous especially for small farmers because result in greater protection to the environment when compared to monocultures, provides diversified source of income through the different products to be managed. 
The legal uncertainty of these activities in APPs and RLs, which could serve as obstacle to their implementation, was remedied by Articles 54, 6la and 66. These articles allow the use of SAF to APPs recovery when inserted in small rural properties and recovery of any legal reserves. The new Forest Code also seals its approval because encourages small producers to set up such production methods. According to Art. 58, item III, it is ensured the control and supervision of the competent environmental authorities of respective plans or projects, as well as the obligations of the owner of the property. The government may establish technical support program for small farmers to meet the initiatives deployment of agroforestry and agrosilvopastoral system.

\section{AGROFORESTRY SYSTEMS}

According to Macedo (2000), SAFs are systems of use and management of natural resources that integrate syndications of trees and agricultural crops and / or animals scientifically and ecologically desirable, practically feasible and socially acceptable by the farmers, in a way that he gets benefits of ecological interactions and economic result.

The author adds that this agricultural production system is founded on principles of the triad of sustainability because they involve economic, social and environmental aspects. About the economic side, it is noticed that the diversity of products obtained by SAF generates greater employment opportunities in rural areas, once it is required a wide variety of labor for handling and managing it, and this system protects the farmer against drops in the market price, which do not reach all products at the same time. In the social sphere, SAF when implemented in a specific place or region, have an important function, because it is a way to settle farmers in rural areas in consequence of increasing hand labor, which has a better distribution during the year, and also provides improvement of living conditions due to the diversity of agricultural production. Closing the triad of sustainability, there is the environmental principle, which results from biological diversity promoted by the presence of different species of plants and/or animals that exploit diverse niches within the system.

\section{Advantages and disadvantages of agroforestry system}

Oliveira (2012) states that there are at least three negative aspects in relation to SAF that need to be guided. The first concerns the technical knowledge regarding the best combinations for each region. Embrapa's researchers from Acre indicate that there is no ready recipe for SAF, this way, technicians, producers and researchers need to exchange knowledge and to test models that can improve the use and management of natural resources, ensuring the conservation of the environment, profitability and social gains. The second aspect is about SAF be an unusual system causing distrust in farmers, which makes more difficult the adoption of this system. Finally, the interaction of various species in the same area makes the management more complex, requiring more knowledge and technical and scientific skills.

A possible negative effect of SAF is the competitive interference among crops and trees, often favoring diseases, pests and consequently damage to production. Therefore, as explained above by Oliveira (20I2), it is necessary to adjust the management to the area, demanding appropriate expertise.

Dubois et al. (1996) also list some disadvantages. They considerate that the cost of implementation may be higher, especially when the seedlings of forest species need to be bought in nurseries; the management of SAF's requires more time and it is more difficult if considerate mechanization when compared to other cropping systems; forest component may reduce the yield of agricultural crops and pastures within the agroforestry system; and many products from this system still have limited market and need to form associations with the purpose of seeking better conditions for selling.

Macedo (2000), in turn, points out some disadvantages including the possibility of excessive export of nutrients with crops; the possibility of economic recovery takes longer and the possibility of exploitation of trees for wood or firewood cause damages to associated crops.

Despite all these disadvantages, some authors such as Anderson and Sinclair (1993) believe that the advantages outweigh the cited disadvantages, being better to use agroforestry systems instead of monoculture. Although SAFs do not fulfill with all the environmental services the way makes the natural vegetation, the idea of occupation of this form of low-impact agriculture in consolidated areas brings significant gains for the environment when compared to monocultures, whether in soil conservation, protection against erosion, increase water infiltration rate and ensure the sustainability of the property production.

Dubois et al. (1996) listed some agroforestry system advantages such as: the system makes the work more comfortable due to the use of the tree component, which promotes shadows, consequently promoting greater work performance than in full sun, resulting in 
preservation of their health; assists in the protection and conservation of the environment because it reduces the need for cutting and burning the forest for expansion of new areas of cultivation; probable reduction of pests and diseases due to the biological balance among pest populations and natural enemies that exist in the location; utilization of various species and consequent nutritional demands that allow a better utilization of available natural resources; reduced need for inputs; increases and improves the distribution of family income; good alternative to recover degraded areas because it enables to use nutritionally undemanding species, which are able to improve soil productivity; and reduced rural exodus due the fact that the system can maintain land productive throughout the year.

In addition to achieve greater diversity of products, these systems when properly managed may potentiate the beneficial effects of interactions among animals, crops and arboreal components, enabling the exploitation of the benefits offered by the diversity and succession process. Macedo (2000) points out as positive factor, the decreasing in weed control because the presence of canopy formed by trees reduces the solar radiation that reaches the understory of agroforestry plantation, preventing the establishment of invasive plants that demand high light quantity.

Finally, one of the aspects that could serve as an impediment to the adoption of the service by small producers was implementation costs and maintenance. However, it is possible to keep them within the limits acceptable to farmers, ensuring profitability and hence the sustainability of the activity rural. Macedo (2000) also notes that despite the implementation requires a lot of hand labor, the perennial species can be grown in white crop and reducing costs. In addition, after implemented, the system does not require lots of manpower, only management expertise.

\section{SAF, sustainable alternative of intervention/ recovery of Area of Permanent Preservation and Legal Reserve by small farmers}

As deforestation rates continue to rise in many parts of the country, environmental authorities are facing the challenge of finding approaches that can reduce it, and at the same time, provide rural livelihoods. The conversion and fragmentation of forests because of agricultural intensification is typically identified as the most prominent conductive of loss and change of the country's biodiversity.
The implementation of measures for recovering of forest fragments demands high investments by farmers, what makes necessary to develop alternatives to reduce this investment and to contribute with the broad dissemination and implementation of projects for environmental recovery (AMADOR; VIANA, 1998).

Many studies have shown that small farmers, due to agricultural production capacity combined with environmental protection, can adopt Agroforestry Systems. Why do not we use them in intervention of areas already established or in the restoration of protected areas that need extra care?

Amador and Viana (1998) believe that SAF can be used as a method of forest fragments recovering, where the goal is not the continuous production of agricultural products, but production in the early years after the implementation of the recovery project to make it viable economically. This way, in addition to retrieve and promote the conservation of water and soil, reduction of inputs and pesticides, adequacy of small property and biodiversity conservation, SAF can support the area economically, which in turn influences the social aspect.

Bhagwat et al. (2008) and Mcneely and Schroth (2006) argue that agroforestry can relieve the pressure on the use of resources in protected areas, improve the habitats for some wildlife species and increase the connectivity of landscape's components, making the conservation more effective .

Although these systems do not restore important features of forest communities, such as structure and biodiversity, when well elaborated, they can be more similar ecologically to these communities. As a result, the system can recover the essential functions for sustainability such as nutrient cycling, and provide income and livelihood to the farmer (MACDICKEN; VERGARA, 1990).

Brienza Junior and Yared (199I) observed that most of Amazonian soils are highly weathered, acid and with low fertility, and therefore, usually a small area of the forest is cut, burned and used to grow crops for two to three years, and then abandoned. Many of these regions were used to remain about three years fallow system, but where the population density was lower; this system could reach ten years or more. Thus, they began a search in the Tapajós region in the Amazon, aiming to help small farmers adopt more sustainable agricultural practices in environmental terms, in addition to obtaining an additional source of money. The authors concluded that the SAF might not necessarily be an ideal solution for the whole Amazon. However, there is a consensus that these systems could establish a strategic form of rational 
use of natural resources, providing moderate farm income and maintaining the integrity of the forest landscape.

In the Tapajós region in Amazon, Tremblay et al. (2015) studied agroforestry systems to verify their economic advantages over the traditional practice of coivara (cultivation in that first there is suppression of vegetation and burning for site cleaning to be used) still widely used by small rural farmers. The researchers did an analysis of the net present value and found that agroforestry systems can recover the total cost of implementation and operation in twenty years in time horizon. The researchers said that the current public policies favor the implementation of these environmentally sustainable systems through credit support and agricultural knowledge to farmers.

Souza et al. (2012) sought to determine the contribution of agroforestry systems to biodiversity and to long-term effects on the microclimate conditions, temperature and chemical and biological characteristics of the soil, tested by farmers since 1993 in the Zona da Mata, Minas Gerais State in Brazil. Due to the adoption of conventional agricultural activities on the steep slopes of this area, the observed result was severe soil erosion and problems with the quality of soil. For this reason, residents of the Zona da Mata, Minas Gerais, are facing edaphic degradation problems, decreased production and loss of biodiversity. When SAF was tested in this region, it was found that $78 \%$ of tree species were native, contributing to greater $\gamma$ diversity than a diversity. The monthly average temperature was about six degrees higher in coffee monocultures in full sun than in coffee interspersed in the SAF, and when the system was used the soil quality was better than the soil of coffee monoculture.

The use of SAF also works as a sustainable alternative to recover degraded pasture because this system has the ability to promote improvements in physical, chemical and biological soil properties (Macedo, 2000). Another possibility of SAF adopting refers to the restoration of Legal Reserve. In this case, SAF could be practiced until canopy closure phase of tree/shrub vegetation, as an agrissilvicultural system, and later by the adoption of silvopastoral systems.

Rodrigues et al. (2007), developed a survey in the settlement of landless rural workers in Santa Zelia, municipality of Teodoro Sampaio in São Paulo State, in an area of I 5 ha of Legal Reserve where six families restored the area through agroforestry modules (Taungya). These families did soil preparation, and to prevent soil erosion they used plants such as guandu bean (Cajanus cajan) and lab-lab (Dolichos lablab), which are species of nitrogen- fixing legumes. In this area, SAF was an interesting strategy because soil and climatic conditions of the region are inappropriate for cultivation and development of various agricultural crops. So, agroforestry could represent an alternative to the diversification of the property. They used as indicators for economic evaluation of agricultural production in the area the Net Present Value (NPV) and Benefit-Cost (RB / C). The results were positive for all families, leading to the conclusion that the systems can be adopted for the recovery of RL areas.

Vieira et al. (2009), found that for centuries, farmers and scientists have developed various agroforestry techniques and management practices used in these systems that are parallel to those used in many forest restoration efforts. According to the authors there is a synergism among these approaches as evidenced by many examples used by small farmers in the tropics. As benefits, they highlighted food security, compensation management costs for the marketing of products from these systems and the involvement of small farmers in the restoration process.

Finally, in relation to new concerns about carbon sequestration for mitigation of climate change, SAFs prove to be a promising alternative compared to the traditional farming processes. Ehrenbergerová et al. (2016), in their study in Peru, found that these systems play an important role in carbon sequestration in agricultural landscapes that have lost their original coverage, being especially important in tropical areas that have suffered deforestation for the expansion of land farmable.

\section{FINAL CONSIDERATION}

It is recognized the importance of legal standards edition for environmental protection, but alone they do not provide sufficient protection to ensure the conservation of nature. An example of this can be seen through the permission of the consolidated anthropic use and lowimpact activities in Areas of Permanent Preservation, which compromises these areas under-risk of impacts, often irreversible, if the proper techniques are not adopted.

Agroforestry System is a strategic alternative for intervention and recovery of APPs and RLs to small producers who are not in accordance with the law. In consolidated APPS and RLs, the replacement of monocultures by SAF may improve the ecological interactions and provide greater balance of the local ecosystem.

The benefits of SAF depend on a number of factors such as the landscape in which it operates, its relationship with the remaining, their management and the design of the system in its structure and diversity. Thus, it is 
recommended the SAF application with the appropriate mix of species that are aimed the improvement of use and occupation of land, the increasing productivity without forgetting the preservation and environmental services.

Rural properties should always seek the innovation, reduce the production costs and increase profitability with environmental responsibility, being that agroforestry system has been shown to be an alternative that brings together production with environmental protection. Therefore, it is necessary, by the environmental agencies and rural extensions, to promote technical and credit support to producers that encourage the adherence to these production methods in consolidated rural areas.

\section{REFERENCES}

AMADOR, D. B.; VIANA, V. M. Sistemas agroflorestais para recuperação de fragmentos florestais. Série técnica IPEF, v. 12, n. 32, p. 105-I 10, 1998.

ANDERSON, L. S.; SINCLAIR, F. L. Ecological interactions in agroforestry systems. Forestry Abstracts, v. 54, n. 6, p. 489-523, 1993.

BHAGWAT, S. A.; WILLIS, K. J.; BIRKS, H. J. B.; WHITTAKER, R. J. Agroforestry: a refuge for tropical biodiversity? Trends in Ecology \& Evolution, v. 23, n. 5, p. 26I-267, 2008.

BORGES, L. A. C.; REZENDE, J. L. P.; PEREIRA, J. A. A.; COELHO JÚNIOR, L. M.; BARROS, D. A. Áreas de Preservação Permanente na legislação ambiental brasileira. Ciência Rural, v. 4I, n. 7, p. I202-1210, 2011.

BRAGA, T. M.; FREITAS, A. P. G.; DUARTE, G. S.; CAREPASOUSA, J. Índices de sustentabilidade municipal: o desafio de mensurar. Nova Economia, v. I4, p. I I-33, 2004.

BRANCALION, P. H. S.; GARCIA, L. C.; LOYOLA, R.; RODRIGUES, R. R.; PILLAR, V. D.; LEWINSOHN, T. M. A critical analysis of the Native Vegetation Protection Law of Brazil (20I2): updates and ongoing initiatives. Natureza \& Conservação, v. I4, n. I, p. I- I5, 2016.

BRASIL. Lei $\mathbf{n}^{\circ} \mathbf{1 2 . 6 5}$ I, de 25 de maio de 2012 . Instituiu - Novo Código Florestal Brasileiro. Diário Oficial da República Federativa do Brasil, Brasília, DF. Available at: https://www.planalto.gov.br. Acessed in: Jun 22, 2016.

BRIENZA JUNIOR, S.; GAZEL YARED, J. A. Agroforestry systems as an ecological approach in the Brazilian Amazon development. Forest Ecology and Management, v. 45, n. I, p. 319-323, I99|.

CONAMA. CONSELHO NACIONAL DO MEIO AMBIENTE. Resolução $n^{\circ}$ 369, de 28 de março de 2006. Dispõe sobre os casos excepcionais, de utilidade pública, interesse social ou baixo impacto ambiental, que possibilitam a intervenção ou supressão de vegetação em Área de Preservação Permanente - APP. Diário Oficial da República Federativa do Brasil, Brasília, DF. Available at: http://www. mma.gov.br/conama. Acessed in: Jun 19, 2016.
CONAMA. CONSELHO NACIONAL DO MEIO AMBIENTE. Resolução $n^{\circ}$ 425, de 25 de Maio de 2010. Dispõe sobre sobre critérios para a caracterização de atividades e empreendimentos agropecuários sustentáveis do agricultor familiar, empreendedor rural familiar. Diário Oficial da República Federativa do Brasil, Brasília, DF. Available at: http://www.mma.gov.br/conama. Acessed in: Jun 19, 2016.

DUBOIS, J. C. L.; VIANA, V. M.; ANDERSON A. B. Manual agroflorestal para a Amazônia. REBRAF, 1996. 228p.

EHRENBERGEROVÁ, L.; CIENCIALA, E.; KUCERA, A.; GUY, L.; HABROVÁ, H. Carbon stock in agroforestry coffee plantations with different shade trees in Villa Rica, Peru. Agroforestry Systems, v. 90, n. 3, p. 433-445, 2016.

MACDICKEN, K. G.; VERGARA, N. T. Introduction to agroforestry. In: MACDICKEN, K. G.; VERGARA, N. T. Agroforestry: classification and management. John Wiley \& Sons, 1990. p. I-30.

MACEDO, R. L. G. Princípios básicos para o manejo sustentável de sistemas agroflorestais. UFLA/FAEPE, 2000. 157p.

MCNEELY, J. A.; SCHROTH, G. Agroforestry and biodiversity conservation - traditional practices, present dynamics, and lessons forthe future. Biodiversty Conservation, v. 15, p. 549-554, 2006.

OLIVEIRA, T. K. Sistemas agroflorestais: vantagens e desvantagens. 20I2. Available at: http:/www.cpafac. embrapa.br/imprensa/artigos_tecnicos/artigos-de-midia-3/ artigos-de-midia-2003/sistemas-agroflorestais-vantagense-desvantagens. Acessed in: Mar 03, 2015.

RODRIGUES, E. R.; CULLEN JR, L.; BELTRAME, T. P.; MOSCOGLIATO, A. V.; SILVA, I. C. Avaliação econômica de sistemas agroflorestais implantados para recuperação de reserva legal no Pontal do Paranapanema, São Paulo. Revista Árvore, v. 3I, n. 5, p. 94I-948, 2007.

SILVA, J. A. A.; NOBRE, A. D.; MANZATTO, C. V.; JOLY, C. A.; RODRIGUES, R. R., SKORUPA, L. A.; NOBRE, C. A.; AHRENS, S.; MAY, P. H.; SÁ, T. D. A.; CUNHA, M. C.; RECH FILHO, E. L. O código florestal e a ciência: contribuiçõos para o diálogo. SBPC, 20II. 124p.

SKORUPA, L. A. Áreas de preservação permanente e desenvolvimento sustentável. Embrapa Meio Ambiente, 2003. 4p.

SOARES-FILHO, B.; RAJÃO, R.; MACEDO, M.; CARNEIRO, A.; COSTA, W.; COE, M.; RODRIGUES, H.; ALENCAR, A. Cracking Brazil's forest code. Science, v. 344, n. 6182, p. 363-364, 2014.

SOUZA, H. N.; GOEDE, R. G. M.; BRUSSAARD, L.; CARDOSO, I. M.; DUARTE, E. M. G.; FERNANDES, R. B. A.; GOMES, L. C.; PULLEMAN, M. M. Protective shade, tree diversity and soil properties in coffee agroforestry systems in the Atlantic Rainforest biome. Agriculture, Ecosystems \& Environment, v. I46, n. I, p. 179-196, 2012. 
TAMBOSI, L. R.; VIDAL, M. M.; FERRAZ, S. F. B.; METZGER, J. P. Funções eco-hidrológicas das florestas nativas e o Código Florestal. Estudos Avançados, v. 29, n. 84, p. I5I-162, 2015.

TREMBLAY, S.; LUCOTTE, M.; REVÉRET, J. P.; DAVIDSON, R.; MERTENS, F.; PASSOS, C. J. S.; ROMAÑA, C. A. Agroforestry systems as a profitable alternative to slash and burn practices in small-scale agriculture of the Brazilian Amazon. Agroforestry Systems, v. 89, n. 2, p. 193-204, 2015.
TUNDISI, J. G.; TUNDISI, T. M. Impactos potenciais das alterações do Código Florestal nos recursos hídricos. Biota Neotropica, v. 10, n. 4, p. 67-76, 2010.

VIEIRA, D. L. M.; HOLL, K. D.; PENEIREIRO, F. M. Agro $\square$ Successional Restoration as a Strategy to Facilitate Tropical Forest Recovery. Restoration Ecology, v. I7, n. 4, p. 45I459, 2009. 
